\title{
A NOTE ON THE PREY AND A NESTING SITE OF CERCERIS TRUNCATA CAMERON (HYMENOPTERA: SPHECIDAE: PHILANTHINAE)
}

\author{
By F. G. WERNER \\ Department of Entomology, University of Arizona
}

This species seems to be very rare or extremely local in southern Arizona; Dr. H. A. Scullen, who has kindly provided the identification, held it as undescribed until he discovered that it had been described from Mexico by Cameron. However, there is a rather extensive nesting site in my own yard, at 1247 N. Warren Ave., Tucson. During the past four years I have been able to observe the habits of the species regularly and have found that the females store only beetles of the family Bruchidae (Mylabridae). The species stored at this site are all of medium size, and probably all come from leguminous trees and shrubs in the neighborhood. In order of abundance the bruchids gathered are: Algarobius prosopis (Lec.), Mimosestes protractus (Horn), Mimosestes amicus (Horn) and Neltumius arizonensis (Schffr.); this is roughly the relative abundance of these species when they are taken in general collecting. The most abundant source tree in the neighborhood is the so-called Mexican palo verde, Parkinsonia, which is planted extensively, blooms in the spring and has mature pods by mid-July, when the wasps become active.

The site occupied is on flat ground in the southwestern corner of the lot, about $\mathrm{IO}^{\prime} \times \mathrm{IO}^{\prime}$, shielded on south and west by a five-foot wall and partly shaded by large oleander bushes; the soil is bare and consists of well-packed fill about eight inches deep over caliche; almost all of the water that reaches it comes from rainfall. Activity of the wasps was checked weekly in 1958, when the first swarms of males and starts of nests were observed on July 20 and could not have started more than a week before this date. The males fly continually during the day, just over the oleander bushes and nearby vegetation, stopping occasionally to rest. Hundreds of individuals are involved in these flights. Smaller numbers, usually about twenty, patrol the nesting site, flying about four inches above the ground, and attempt copulation with females flying in the area or returning to their nests with prey. I could not discover where the males went at night. The females dig small holes, either bare or with a low mound up to $\mathrm{I} / 2$ " in diameter. Most of their flying and provisioning activity occurs in the morning but even then the principal activity seems to consist of sitting in the nest entrance with only the front of the head exposed. By noon all 
is quiet and most of the nest entrances are loosely plugged, only the occasional pushing up of dirt in some of the nests indicating that digging may be in progress. Marked nests were open for two or three days, except when they were plugged with loose dirt in the afternoon, and one nest was open at least five days. The nests were hard to keep track of during the period of observation because of frequent rains. By July 27 there were 55 nests in a marked area $4^{\prime} \times 4^{\prime}$ and there were at least this many active during the rest of the summer. Solenopsis ants raided part of the site but there was no sign of social or other parasites.

Individual nests were dug up but none could be excavated completely. The holes could be followed down to about 4", where they seemed to end in loose dirt; below some of them, at $5^{\prime \prime}$ to $6^{\prime \prime}$, a cluster of up to ten bruchids, with an egg or larva, indicated where the cell must have been. The cells must be of very loose construction. Nesting activity and male swarming continued from mid-July well into September in 1958, gradually diminishing during the latter month. A similar schedule has been maintained in the two succeeding years. No adults have been seen until July, the normal starting time of the summer monsoon season.

\section{THE TYPE SPECIES OF THE ANT GENUS EURHO-} $P A L O T H R I X$. - In our paper, "A world revision of the ant tribe Basicerotini," Studia Entomologica, Petrópolis, Brazil, 3: 202, I960, we erected a new genus Eurhopalothrix to receive certain species formerly placed in Rhopalothrix Mayr, along with some new species. Through inadvertance, no type species was cited for the new genus, and we therefore here designate Eurhopalothrix bolaui (=Rhopalothrix bolaui Mayr, I870) as type species of the genus Eurhopalothrix Brown and Kempf. - W. L. Brown, JR., Department of Entomology, Cornell University, Ithaca, N. Y., and W. W. Kempf, o. F. M., São Paulo, Brazil. 

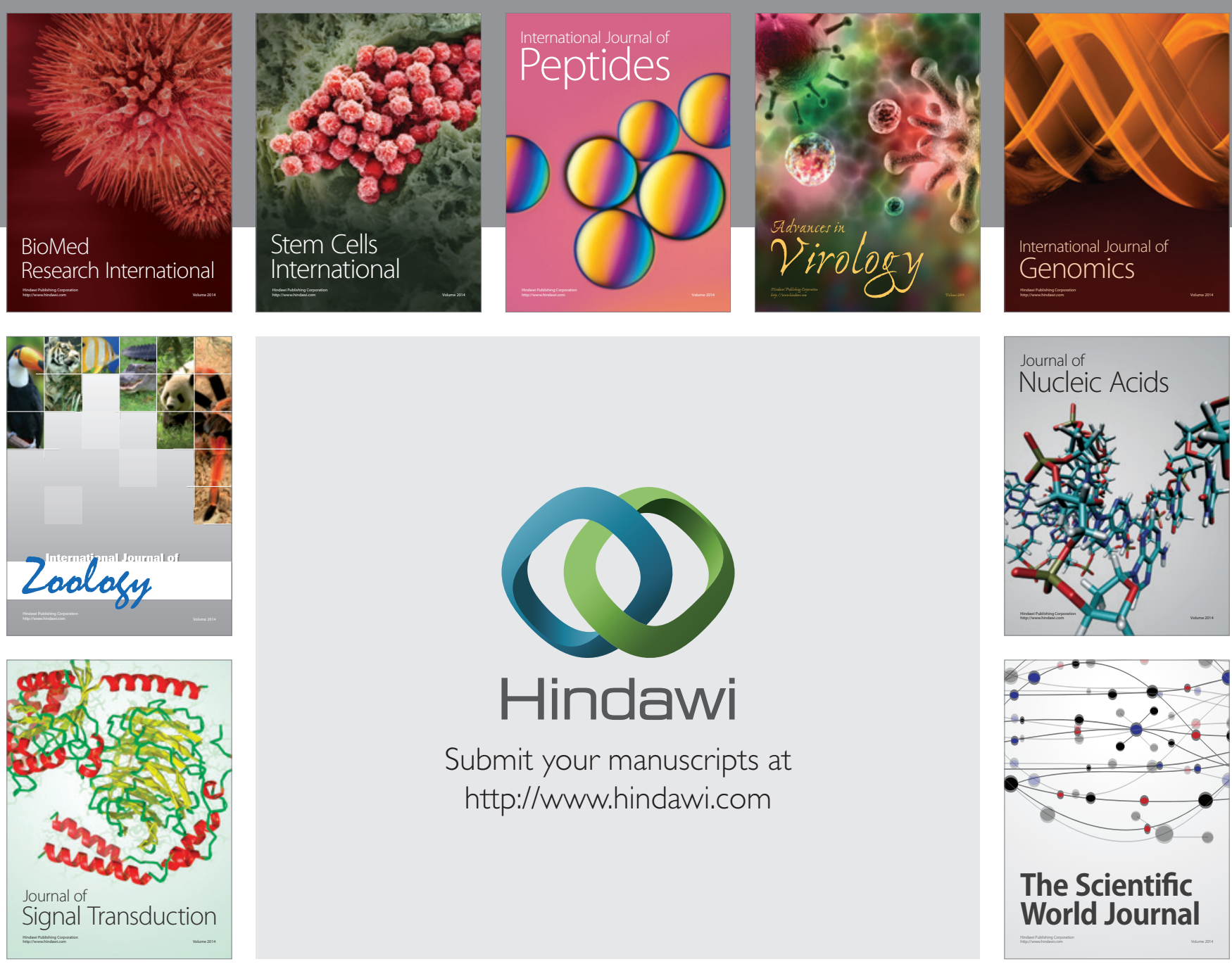

Submit your manuscripts at

http://www.hindawi.com
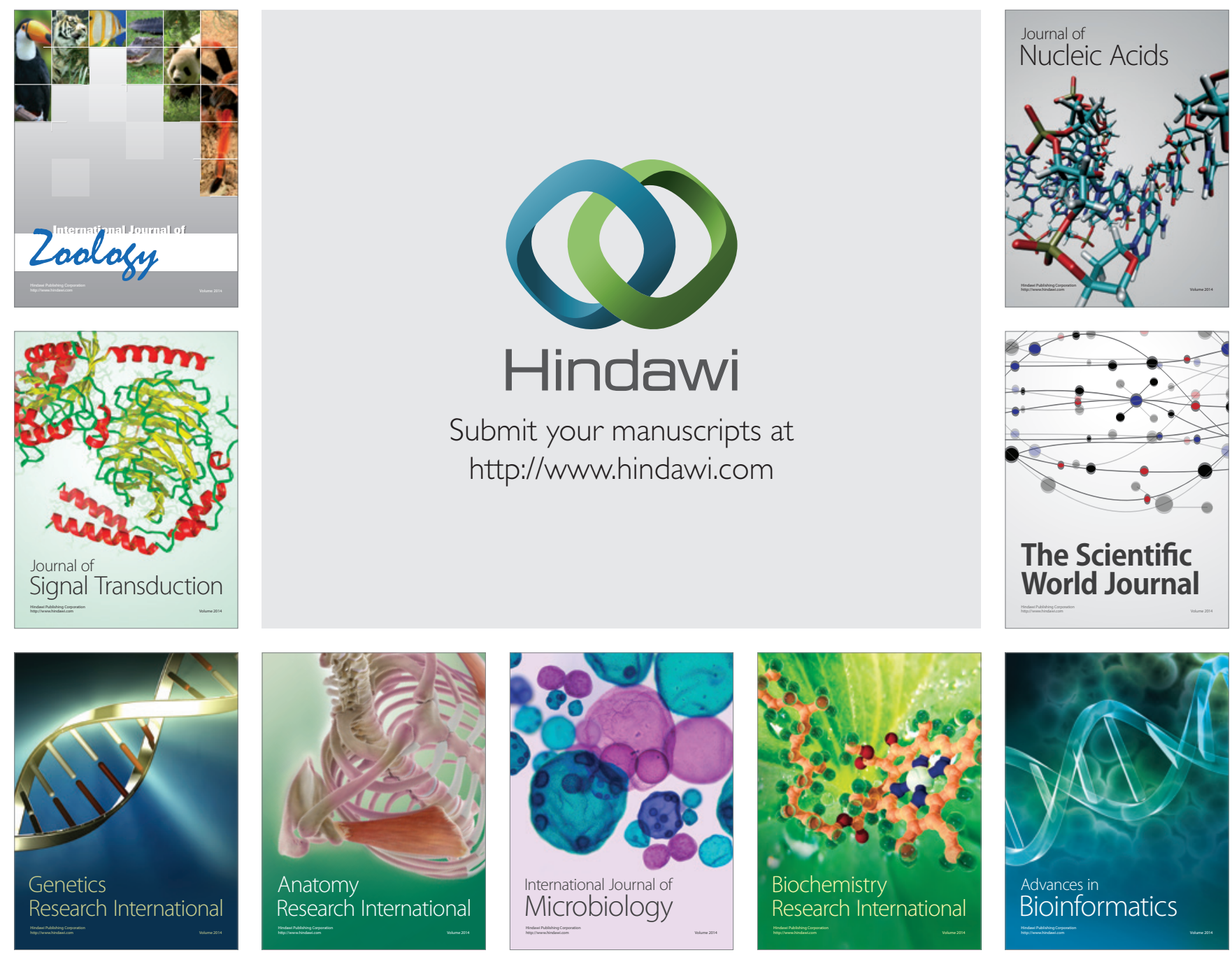

The Scientific World Journal
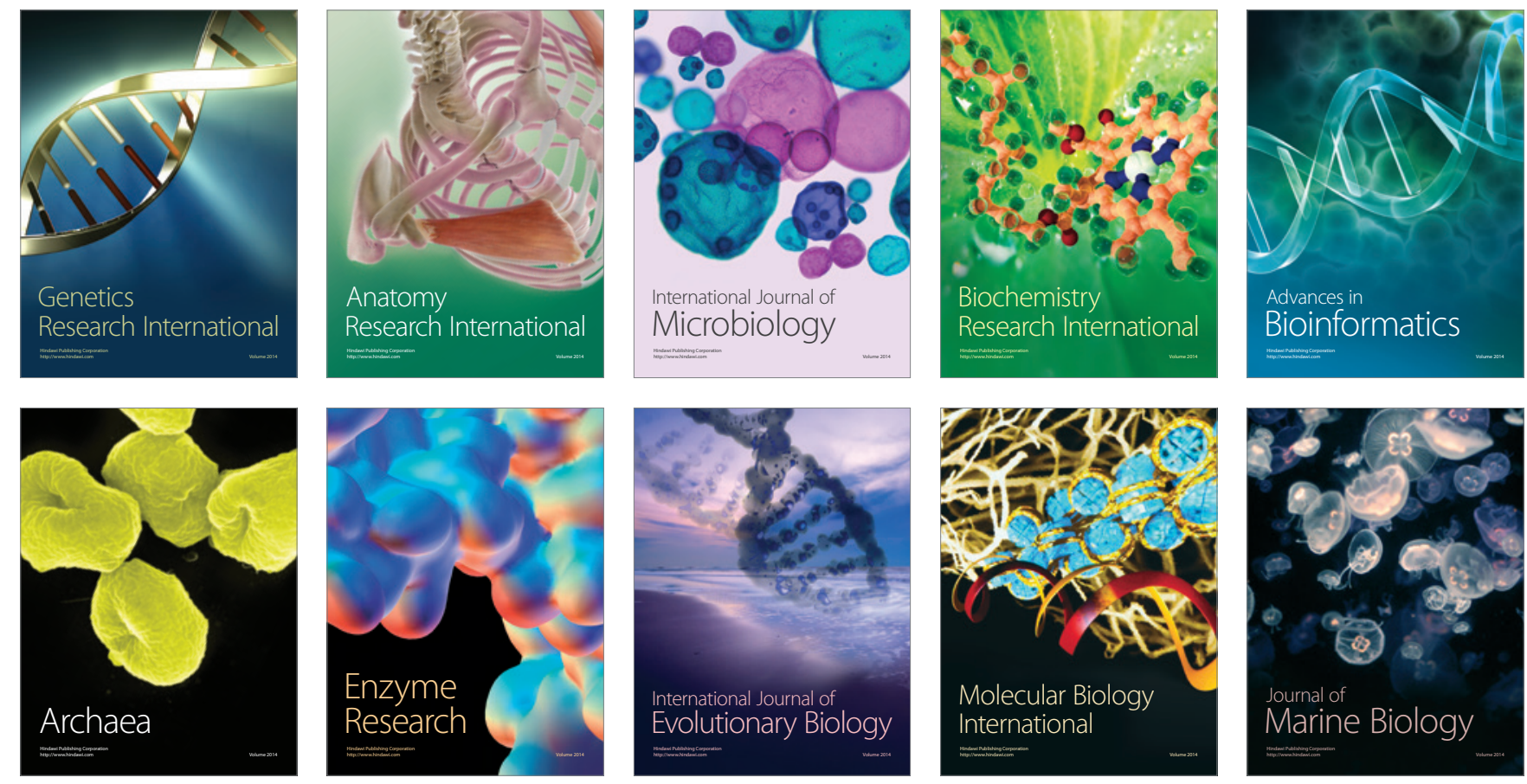